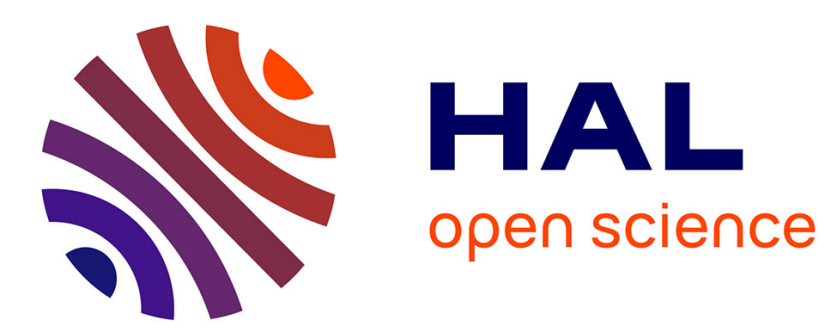

\title{
Phenotypic Changes in Different Spinach Varieties Grown and Selected under Organic Conditions
}

Estelle Serpolay, Nicolas Schermann, Julie Dawson, Edith Lammerts van

Bueren, Isabelle Goldringer, Veronique Chable

\section{- To cite this version:}

Estelle Serpolay, Nicolas Schermann, Julie Dawson, Edith Lammerts van Bueren, Isabelle Goldringer, et al.. Phenotypic Changes in Different Spinach Varieties Grown and Selected under Organic Conditions. Sustainability, 2011, 3 (9), pp.1616-1636. 10.3390/su3091616 . hal-01458583

\section{HAL Id: hal-01458583 \\ https://hal.science/hal-01458583}

Submitted on 29 May 2020

HAL is a multi-disciplinary open access archive for the deposit and dissemination of scientific research documents, whether they are published or not. The documents may come from teaching and research institutions in France or abroad, or from public or private research centers.
L'archive ouverte pluridisciplinaire HAL, est destinée au dépôt et à la diffusion de documents scientifiques de niveau recherche, publiés ou non, émanant des établissements d'enseignement et de recherche français ou étrangers, des laboratoires publics ou privés. 


\title{
Phenotypic Changes in Different Spinach Varieties Grown and Selected under Organic Conditions
}

\section{Estelle Serpolay ${ }^{1, *}$, Nicolas Schermann ${ }^{1}$, Julie Dawson ${ }^{2}$, Edith T. Lammerts van Bueren ${ }^{3}$, Isabelle Goldringer ${ }^{2}$ and Véronique Chable ${ }^{1}$}

1 INRA, Unité SAD Paysage, Institut National de la Recherche Agronomique, 65 rue de Saint-Brieuc, F-35042 Rennes, France; E-Mails: nicolas.schermann@rennes.inra.fr (N.S.); veronique.chable@rennes.inra.fr (V.C.)

2 INRA, UMR 320 Génétique Végétale, Institut National de la Recherche Agronomique, Ferme du Moulon, F-91190 Gif-sur-Yvette, France; E-Mails: dawson@moulon.inra.fr (J.D.); isabelle.goldringer@moulon.inra.fr (I.G.)

3 Louis Bolk Institute, Hoofdstraat 24, NL-3972 LA Driebergen, The Netherlands; E-Mail: e.lammerts@louisbolk.nl

* Author to whom correspondence should be addressed; E-Mail: estelle.serpolay@rennes.inra.fr Tel.: +33-2-23-48-56-24; Fax: +33-2-23-48-56-20.

Received: 9 June 2011; in revised form: 17 August 2011 / Accepted: 24 August 2011 / Published: 23 September 2011

\begin{abstract}
Organic and low-input agriculture needs flexible varieties that can buffer environmental stress and adapt to the needs of farmers. We implemented an experiment to investigate the evolutionary capacities of a sample of spinach (Spinacia oleracea L.) population varieties for a number of phenotypic traits. Three farmers cultivated, selected and multiplied one or several populations over two years on their farms. The third year, the versions of the varieties cultivated and selected by the different farmers were compared to the original seed lots they had been given. After two cycles of cultivation and on-farm mass selection, all the observed varieties showed significant phenotypic changes (differences between the original version and the version cultivated by farmers) for morphological and phenological traits. When the divergence among versions within varieties was studied, the results show that the varieties conserved their identity, except for one variety, which evolved in such a way that it may now be considered two different varieties. The heterogeneity of the population varieties was assessed in comparison with a commercial F1 hybrid used as control, and we found no specific differences in phenotypic
\end{abstract}


diversity between the hybrid and population varieties. The phenotypic changes shown by the population varieties in response to on-farm cultivation and selection could be useful for the development of specific adaptation. These results call into question the current European seed legislation and the requirements of phenotypic stability for conservation varieties.

Keywords: Spinacia oleracea; on-farm conservation; farmer varieties; participatory plant breeding; seed legislation; DUS

\section{Introduction}

Seed is an input of importance in agriculture. For each crop, farmers have to choose, according to their farming system, from a range of different types of varieties, based on genetic, phenotypic, commercial, social or cultural characteristics. In Europe, the seed market is regulated: commercialized seeds have to meet a number of standards set by law. The main one is the registration of the variety in an official catalogue, which requires it to meet Distinctiveness, Uniformity and Stability (DUS) criteria [1]. These criteria are evaluated by visual assessments in trials performed by specialized institutions. Today, most marketed varieties (created by seed companies) are F1 hybrids or pure lines, which are visually very uniform and stable since they are genetically homogeneous (all the plants of the variety have the same genotype). Other types of varieties, like populations or open pollinated varieties are less homogeneous (more diverse) from a genetic and phenotypic point of view. Thus they do not fulfill the legislative DUS requirements and cannot be easily commercialized in the European seed market. They are gaining interest in Europe, especially for low-input (LI) and organic agriculture (OA) farming [2]. In the following, we will refer to organic agriculture (OA) for simplicity, but what is said of OA also applies to low-input agriculture in which limited quantities of chemical inputs are used. To achieve coherence with IFOAM principles, many organic farmers are interested in varieties that can be re-sown, that also have intrinsic genetic diversity because (i) diversity may buffer the variability of cultivation conditions [3], (ii) genetic diversity enables the farmer to select within the variety to adapt it to the specific requirements of its farm (specific markets for example) and (iii) such varieties allow farmers to achieve seed self-sufficiency, especially for allogamous species.

Figure 1 illustrates the strategies used to optimize organic and conventional systems: the first one is based mainly on the choice of plants and the other is mainly based on the proper use of inputs. All intermediate situations are possible in which a balance is established between plant adaptation and inputs. Because professional breeding has primarily targeted conventional agriculture, available varieties on the market present several shortcomings in regards to the aims of organic agriculture. The vast majority of commercial varieties are genetically homogeneous: pure lines for autogamous species, F1 hybrids for allogamous species and F1 hybrids for many autogamous vegetable species. Resowing seeds resulting from the crop of these commercial varieties either will not give a proper crop in the case of F1 hybrids, or is subjected to a fee for pure lines in some European Union (EU) countries, such as in France. Furthermore, there are very few varieties specifically bred for organic and low-input conditions. This is the case for spinach, the crop under discussion in this article [4]. Finally, using little 
or no chemicals asks for more resilience from the varieties in order to best exploit environmental conditions. Therefore, due to the specific conditions of OA (great variability of the environment, agronomic practices, end-uses, markets), farmers would like to tailor the varieties to their needs through exchanges with other farmers and selection in their fields. In the case of OA, genetically diverse varieties can benefit from on-farm participatory plant breeding [5-9] in addition to classical breeding, even when classical breeding is conducted under organic conditions.

Figure 1. Strategies of organic and conventional farming systems, focused on seeds and variety use.

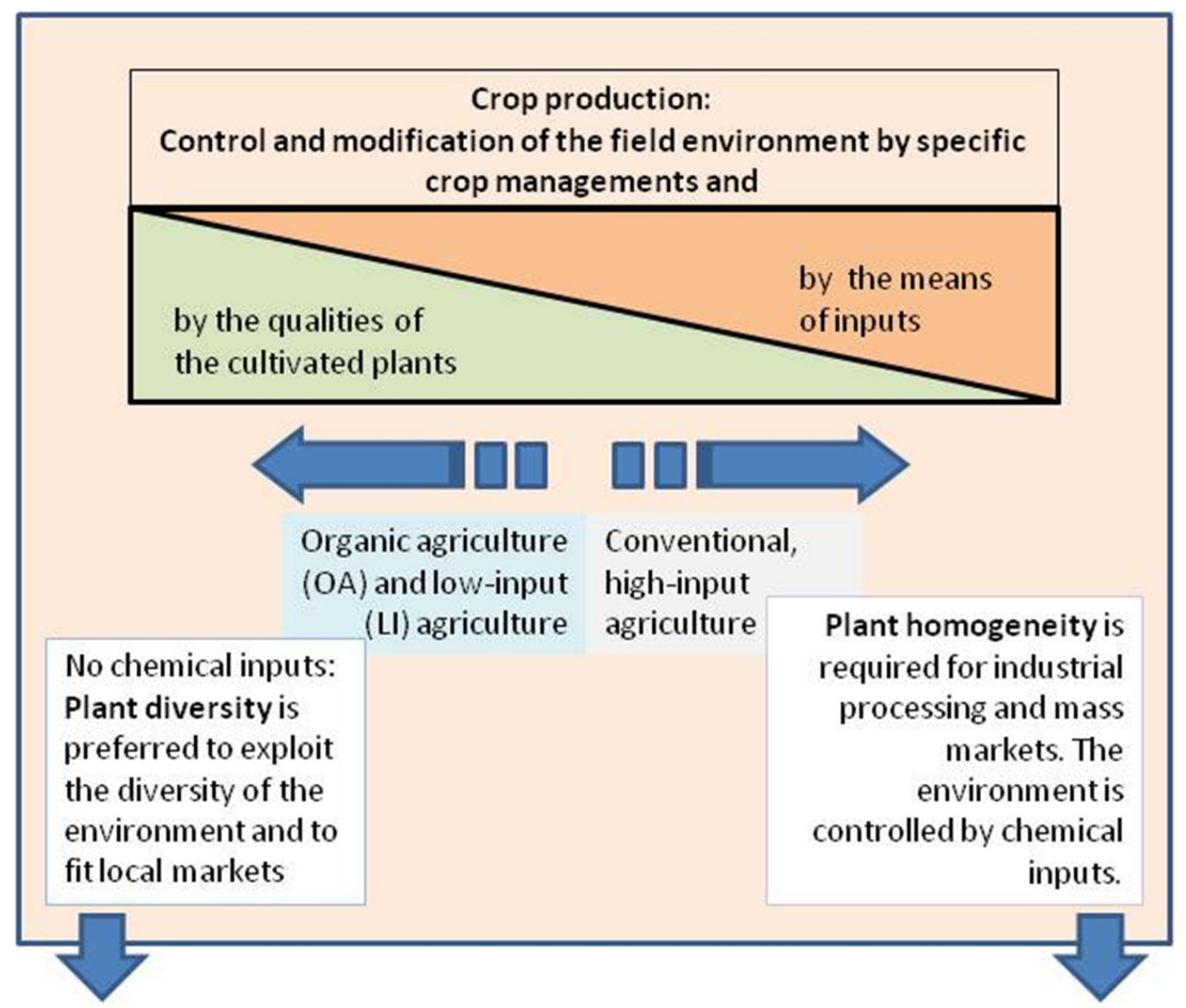

\begin{tabular}{|c|c|}
\hline \multicolumn{2}{|c|}{ Characteristics of varieties: traits } \\
\hline $\begin{array}{l}* \text { adaptation to greater environmental heterogeneity for } \\
\text { stability of performance } \\
* \text { adaptation to the absence or low use of inputs and water: } \\
\text { tolerance of weed competition, diseases, pests and drought } \\
* \text { qualities for local marketing and artisanal processing }\end{array}$ & $\begin{array}{l}\text { * High yield potential in the most favorable conditions } \\
* \text { Homogeneity and stability of crops, suitability for } \\
\text { industrial processing }\end{array}$ \\
\hline \multicolumn{2}{|c|}{ Characteristics of varieties: genetic types } \\
\hline Intravarietal genetic heterogeneity & Intravarietal genetic homogeneity \\
\hline $\begin{array}{l}\text { Populations, mixtures of pure lines or mixtures of populations } \\
\text { (autogamous). } \\
\text { Populations (allogamous species). }\end{array}$ & $\begin{array}{l}\text { Pure lines (autogamous) } \\
\text { F1 hybrids (allogamous species and some autogamous } \\
\text { species) }\end{array}$ \\
\hline
\end{tabular}


Figure 1. Cont.

\begin{tabular}{ll}
\hline \multicolumn{1}{c}{ Characteristics of varieties: germplasm } \\
\hline $\begin{array}{l}\text { Historic and landrace varieties, crosses among historic, } \\
\text { landrace and other farmer varieties. }\end{array}$ & $\begin{array}{l}\text { Improved varieties for conventional agriculture, } \\
\text { backcrosses with historic and landrace varieties, and } \\
\text { sometimes wild or cultivated related species. }\end{array}$ \\
\hline \multicolumn{1}{c}{ Characteristics of varieties: breeding techniques } \\
\hline $\begin{array}{l}\text { Methods which respect the naturalness of the species and avoid } \\
\text { biotechnologies }\end{array}$ & Biotechnologies and conventional breeding methods \\
\hline $\begin{array}{l}\text { Fery little investment of private sector. } \\
\text { PPB programs involving farmers and public sector since the } \\
\text { end of the 20th century }\end{array}$ & $\begin{array}{l}\text { Strong private and public sector investment. Strong } \\
\text { consolidation of breeding companies. }\end{array}$ \\
\hline $\begin{array}{l}\text { In the EU, well known landraces can be registered under a } \\
\text { catalogue of "conservation varieties", but seed multiplication, } \\
\text { cultivation and commercialization is limited to a small region } \\
\text { of origin. A new approach is needed to meet organic seed } \\
\text { demand for heterogeneous varieties }\end{array}$ & $\begin{array}{l}\text { To be marketed, varieties need to answer to DUS norms } \\
\text { (Distinctness, Uniformity and Stability) to be registered } \\
\text { into an official catalogue. }\end{array}$ \\
\hline
\end{tabular}

Given the growing need for historical and landrace (farmer) varieties bred on-farm [10], the EU needed more scientific information on how such varieties evolve and the associated legislative issues (among others DUS criteria), since seed legislation was developed for homogeneous varieties in a conventional agriculture framework [1]. In the literature, results can be found on the evolution of farmer varieties based on genetic markers, for instance [11-13], but there are few results based on phenotypic traits that are of direct relevance to the farmers [12,14]. Thus, in the EU, research programme Farm Seed Opportunities [15], experiments over three years studied on-farm cultivation and selection in contrasting environments of farmer varieties of wheat, maize, bean and spinach. In this paper, we report on the experiments with spinach (Spinacia oleracea L.), an allogamous vegetable species. In addition, a similar trial on bread wheat, an autogamous crop species, is reported [10]. Results to be published later on maize, an allogamous crop species, will enable us to have more insights on the short-term evolution of farmer varieties, and their potential adaptation to farmers' conditions.

Specifically, our study tries to address the following questions: (1) Does farm cultivation and selection over two years lead to statistically significant phenotypic changes in spinach farmer varieties? To what extent have the tested varieties diverged in a two-year timeframe? Are varieties still distinct after on-farm cultivation? (2) If changes are observed, how can we relate them to the cultivation and type of selection experienced by the different varieties? (3) Are there differences of within-variety diversity levels between a F1 hybrid control and the farmer varieties under organic conditions? 


\section{Materials and Methods}

In our study, phenotypic changes of different spinach (Spinacia oleracea L.) population varieties were explored during an experiment over three years, from 2007 to 2009 . The plants were cultivated and selected by organic farmers in contrasted environments (two farmers in Western France and one in The Netherlands). The changes of each variety were assessed by planting all varieties together in the same environment and comparing the original seed sample with the variety cultivated and selected on-farm for two cycles. Figure 2 illustrates the procedure of the trials and Table 1 gives some information about the environments of the different trials. In the rest of the paper, we have called a variety cultivated by a farmer in a given environment over two years a "version" of this variety. The "original version" is the original seed sample. For example, the variety 'Eté de Rueil' was cultivated by two farmers (FD and MC). In our trial, we compared three versions of this variety: the MC version (the variety cultivated for two years by MC), the FD version (the variety cultivated for two years by FD), and the original version (initial seed lot).

Figure 2. Scheme of the "Farm Seed Opportunity" EU project experiment.

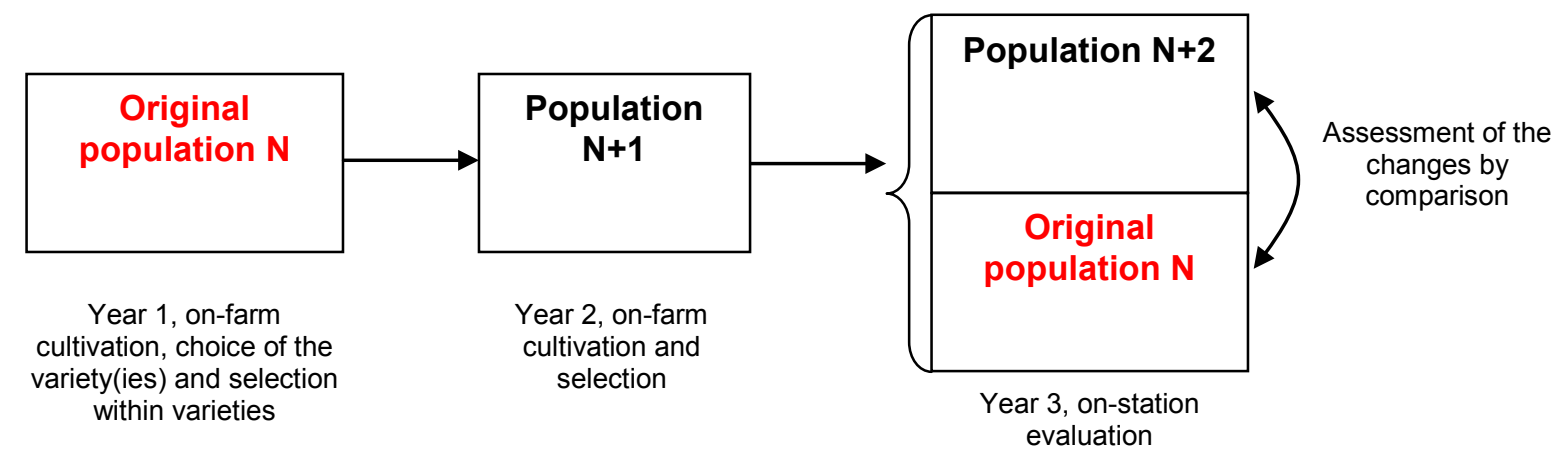

The varieties tested were European populations (open pollinated varieties) of spinach which were historically registered in the European variety catalogue but which have now entered the public domain. Seeds came from national gene banks (CGN_-The Netherlands_-and GEVES—France) and small-scale seed companies (La Semeuse and Germinance, France). Twenty-one varieties were chosen to represent a diverse range of traits that could be of interest for European conditions. All were indicated to be spring varieties. The different varieties tested are presented in Table 2, with those chosen by the farmers for the experiment indicated. 
Table 1. Information about the trials.

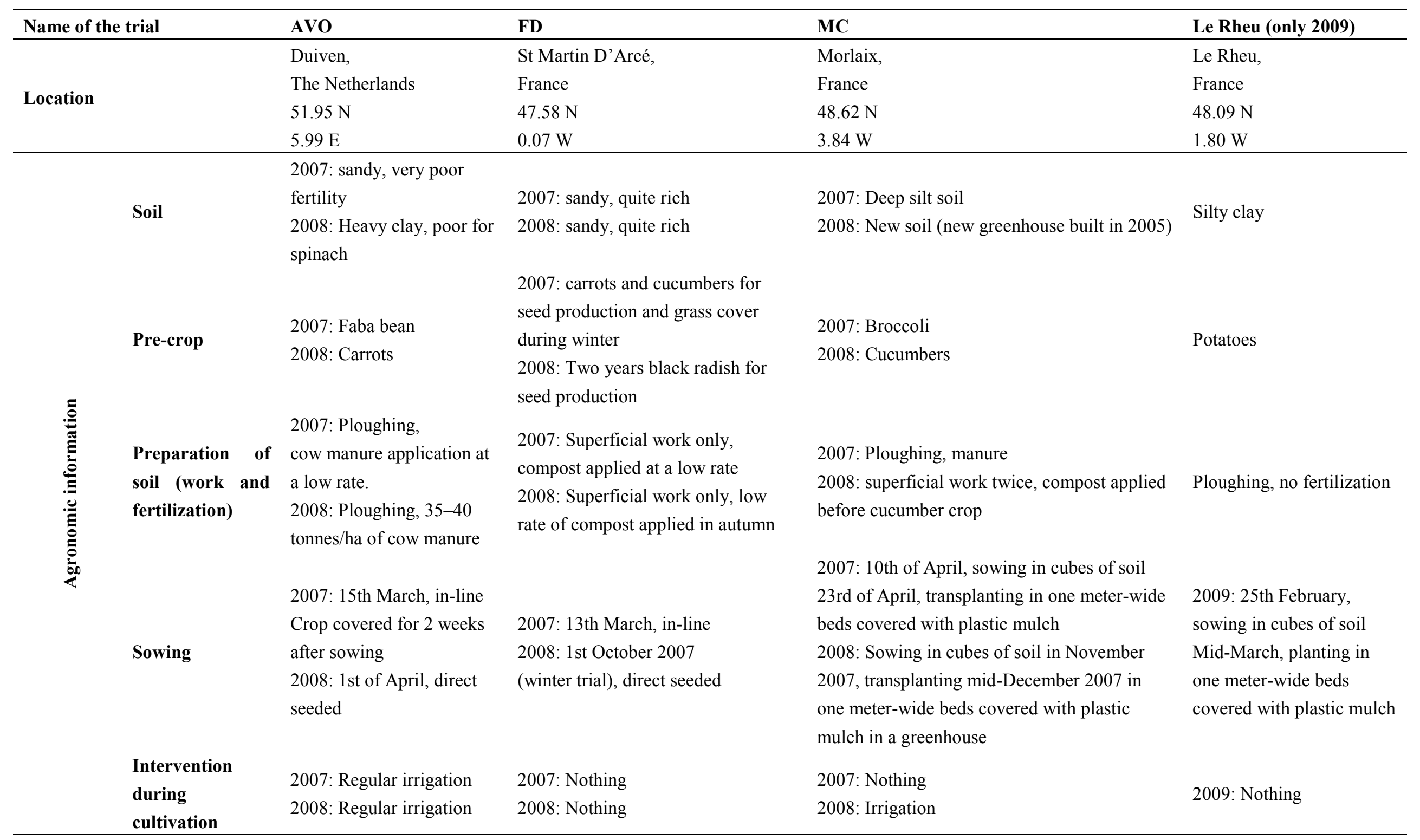


Table 2. Origin of the varieties tested by each farmer the first year of the experiment.

\begin{tabular}{lllll}
\hline Variety name & $\begin{array}{l}\text { Seed bank } \\
\text { or origin }\end{array}$ & $\begin{array}{l}\text { Accession } \\
\text { number }\end{array}$ & $\begin{array}{l}\text { Year of } \\
\text { registration } \\
\text { if registered }\end{array}$ & $\begin{array}{l}\text { Name of the } \\
\text { farmer if } \\
\text { chosen }\end{array}$ \\
\hline Hollandia & CGN & 9421 & 1943 & MC \\
Verbeterde Hollandia & CGN & 9420 & 1943 & \\
Vroeg Reuzenblad & CGN & 9644 & 1943 & \\
Breedblad Scherpzaad Zomer & CGN & 9400 & 1943 & \\
Proloog & CGN & 9440 & 1961 & \\
Resistoflay & CGN & 9442 & 1963 & \\
Duetta & CGN & 14170 & 1962 & \\
Pre Vital & CGN & 9468 & 1962 & \\
Spinoza & CGN & 9451 & 1963 & \\
Virtuosa & CGN & 9466 & 1963 & \\
Amsterdams Reuzenblad & CGN & 14179 & 1943 & \\
Advance & CGN & 14181 & 1955 & \\
Viking & CGN & 9463 & 1943 & MC and FD \\
Nobel & CGN & 14173 & 1943 & MC \\
D'été de Rueil & La semeuse & & & \\
Viking-Matador & Germinance & & & MC \\
Matador foncé & GEVES & 10595 & & MC \\
Monstrueux de Viroflay & GEVES & & & AVO \\
Alwaro & GEVES & 13054 & & \\
Supergreen & GEVES & 14601 & & \\
Monarch Long Standing & GEVES & 14751 & & \\
\hline & & & & \\
\hline
\end{tabular}

\subsection{Trial Design and Observations}

The experiment was performed in three steps: (i) 2007, selection among varieties: cultivation by all the farmers of all twenty-one varieties, with farmers choosing at least one variety to be grown and selected on their farms for the following years; (ii) 2007 and 2008, selection within varieties: on-farm mass selection within the chosen variety(ies) and on-farm multiplication; (iii) 2009: evaluation of all the varieties chosen and selected by the farmers in a common trial (one location, Le Rheu, Brittany, France). As a first step, the farmers chose the variety(ies) to experiment during cultivation and non-suitable varieties were eliminated before flowering. Each farmer chose among the varieties according to their ideotype for fresh-market spinach (see Table 3). 
Table 3. Selection criteria of each farmer for each variety and varieties' changes.

\begin{tabular}{|c|c|c|c|}
\hline Farmer & Criteria of selection & Variety selected & $\begin{array}{l}\text { Significant changes compared to original } \\
\text { version }\end{array}$ \\
\hline AVO & $\begin{array}{l}\text { Ideotype: plants late to bolt and flower } \\
\text { Selection method: transplanting only the } \\
\text { latest plants }\end{array}$ & $\begin{array}{l}\text { 'Monarch Long } \\
\text { Standing' }\end{array}$ & $\begin{array}{l}\text { Shorter petioles } \\
\text { Less bolting and flowering on May } 29\end{array}$ \\
\hline FD & $\begin{array}{l}\text { Ideotype: nothing, wish of increasing diversity } \\
\text { Selection method: no selection in the field but } \\
\text { elimination of the spiny seeds after harvest } \\
\text { ('Eté de Rueil' is supposed to be a variety with } \\
\text { non-spiny seeds) }\end{array}$ & 'Eté de Rueil' & $\begin{array}{l}\text { More anthocyanin } \\
\text { More acute leaves } \\
\text { More bolting and flowering on May } 22 \\
\text { Less bolting and flowering on May } 29\end{array}$ \\
\hline \multirow[t]{6}{*}{$\mathrm{MC}$} & \multirow[t]{6}{*}{$\begin{array}{l}\text { Ideotype: plants with big, dark green, narrow, } \\
\text { spear shaped and smooth leaves } \\
\text { Selection method: negative selection by } \\
\text { elimination of the plants not sufficiently of the } \\
\text { type wished }\end{array}$} & 'Eté de Rueil' & $\begin{array}{l}\text { More « yellow » leaves (chromameter) } \\
\text { More anthocynin on the petiole } \\
\text { More acute leaves } \\
\text { Thicker leaves } \\
\text { More bolting and flowering on May } 22 \text { and } 29\end{array}$ \\
\hline & & 'Supergreen' & $\begin{array}{l}\text { Narrower leaves } \\
\text { More erect leaves } \\
\text { More bolting on June } 4 \\
\text { More flowering on May } 29\end{array}$ \\
\hline & & $\begin{array}{l}\text { 'Verbeterde } \\
\text { Hollandia' }\end{array}$ & $\begin{array}{l}\text { More « yellow » and « green » leaves } \\
\text { (chormameter) } \\
\text { More flowering on May } 29\end{array}$ \\
\hline & & 'Viking' & $\begin{array}{l}\text { More « yellow », « greener » and lighter } \\
\text { leaves (chromameter) } \\
\text { Less erect leaves } \\
\text { More blistered leaves }\end{array}$ \\
\hline & & 'Viking Matador' & $\begin{array}{l}\text { Longer leaves } \\
\text { More bolting on May } 22\end{array}$ \\
\hline & & 'Alwaro' & $\begin{array}{l}\text { Longer petioles } \\
\text { Longer leaves } \\
\text { More « yellow » and « greener » leaves } \\
\text { (chromameter) } \\
\text { More erected leaves } \\
\text { More flowering on May } 22 \text { and } 29 \\
\text { More flowering for all the dates of observation }\end{array}$ \\
\hline
\end{tabular}

When the farmer had chosen several varieties, they were multiplied individually under cages in order to avoid intercrossing. On-farm, the plot size was at least 100 plants and $5 \mathrm{~m}^{2}$ per variety. Selection was carried out differently according to the farmer, and could include the elimination of unsuitable plants, the selection of plants corresponding to a given type, or only through natural selection in their environmental conditions. Three farmers participated in the experiment (MC, FD and AVO). All of them sowed the spinach in spring the first year and two of them (MC and FD) decided to sow the varieties in winter for the second year because, according to their experience, they identified the varieties as winter varieties (although the gene bank identified them as spring varieties). MC 
cultivated the varieties under plastic tunnels and in one-meter-wide beds covered with plastic mulch, FD and AVO cultivated the varieties outside and without plastic mulch.

The common trial of the third year was cultivated in spring, outside in beds with plastic mulch. It was a split-plot design with three replicates. Sub-blocks were composed of 32-plant plots of the different versions of one population variety, i.e., population $\mathrm{N}$ from the gene bank and population(s) $\mathrm{N}+2$ from farmer(s). We added in this common trial a commercial F1 hybrid variety (variety 'Lazio', Voltz seeds) in order to compare levels of intra-varietal variability with the population varieties. Phenotypic traits were observed on 15 plants per replicate for each version of each variety.

Measurements were made on one well-developed and representative leaf of each plant (at the harvestable stage). The traits measured are traits used in the DUS evaluation, however, for DUS tests, traits are assessed at the variety level, considering that the plants are homogeneous. Homogeneity (uniformity) is evaluated at a global level by the number of "off-types" (plant which clearly do not look the same than others). Stability is evaluated by comparison of different seed lots of the variety (year $\mathrm{N}$ and year $\mathrm{N}-5$ for example) and distinctness is validated by visual comparison with other varieties and by comparison with the breeder's description of different traits. In our study, we observed development traits at plot level (bolting and flowering indexes) and the other phenotypic traits at the plant level. The traits observed are presented in Table 4.

Table 4. Traits observed.

\begin{tabular}{ll}
\hline Trait & Details, scale or unit \\
\hline Petiole length & $\mathrm{mm}$ \\
Leaf blade length & $\mathrm{mm}$ \\
Leaf blade width & $\mathrm{mm}$ \\
Leaf blade intensity of green & Visual assessment: 1-very light, 2-light, 3-medium, 4-dark, 5-very \\
& dark \\
Leaf color & Measured with a chromameter-model Minolta CR-200-(average \\
& of 3 measurements per leaf*, each measurement gives 3 parameters: \\
& L (light saturation), A (yellow-blue axis, negative values yellow, \\
& positive values blue, and B (green-red axis, negative values green, \\
& positive values red) (Hunter Labs, 1996)) \\
Anthocyanin on the stem & 1-presence, 2-absence \\
Petiole attitude & 1-horizontal, 2-semi-erect, 3-erect \\
Leaf blade attitude & 1-semi-pendulous, 2-horizontal, 3-semi-erect, 4-erect \\
Leaf blade shape of apex & 1-acute, 2-obtuse, 3-rounded \\
Thickness & 1-very fine, 2-fine, 3 medium, 4-thick, 5-very thick \\
Leaf blade blistering & 1-absent or very weak, 2-weak, 3-medium, 4-strong, 5-very strong \\
Bolting index & 0-not bolted (0\%), 1-very little bolted (1 to 25\%), 2-moderately \\
& bolted (25 to 75\%), 3-bolted (75 to 100\%) \\
& 3 dates of observation: 22 May, 29 May, 4 June, 2009 \\
\hline
\end{tabular}


Table 4. Cont.

\begin{tabular}{ll}
\hline Trait & Details, scale or unit \\
\hline Petiole length & $\mathrm{mm}$ \\
Leaf blade length & $\mathrm{mm}$ \\
Leaf blade width & $\mathrm{mm}$ \\
Flowering index & 0 -not flowered $(0 \%), 1$-little flowered (1 to 25\%), 2-medium \\
& flowered (25 to 75\%), 3-flowered (75 to 100\%) \\
& 3 dates of observation: 22 May, 29 May, 4 June 2009 \\
\hline
\end{tabular}

* The 3 measurements were taken in the three zones of the leaf indicated in Figure 3.

Figure 3. Zones of measurements of leaf blade color with the chromameter.

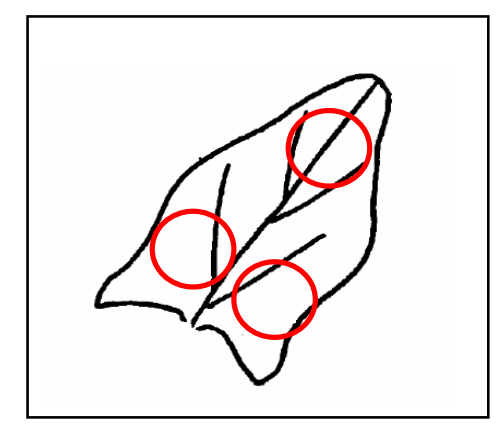

Diseases were not evaluated because they were not present during the growing period.

The selection criteria of the farmers were also collected (see Table 3).

\subsection{Data Analysis}

Each variety was analysed separately. ANOVA tests were performed for quantitative traits $\mathrm{Y}$ (i.e., petiole length, leaf blade length and width and leaf color parameters), according to the model: $\mathrm{Y}_{\mathrm{ijk}}=\mu+$ replicate $_{\mathrm{i}}+$ version $_{\mathrm{j}}+\varepsilon_{\mathrm{ijk}}$ where "version" effect refers to original/farmer versions of a variety. Chi square tests of the version effect were performed on the distributions of the semi-quantitative traits (i.e., anthocyanin, petiole and leaf blade attitude, leaf blade blistering and intensity of green, shape of apex and thickness) after pooling the data of the three replicates. For both ANOVA and Chi square tests, the tests were performed with functions "aov" and "fisher.test" using R software [16] with a significance threshold of 5\%. For bolting and flowering index, we transformed the index in number of plants bolted or flowered at a given date. For this purpose, we multiplied the percentage in the middle of the range of the index by the basic number of plants per plot (32) - we applied $12.5 \%$ for index $1,50 \%$ for index 2 and $87.5 \%$ for index 3 . We applied chi square tests on the new count data. However, in Table 5, for these traits, means of the values in the 3 replicates are given in the 0 to 3 scale.

We performed an ascending hierarchical classification on the variety $\mathrm{x}$ version means for all traits except bolting and flowering indexes in order to assess multi-trait changes of varieties. Data were standardized to a mean of zero and variance of one prior to the analysis, and the Euclidian distance and Ward agglomeration criterion (Ward's minimum variance) were used (function «hclust» in the R freeware was used). Ascending hierarchical classification is a multivariate analysis that leads to groupings of the most similar variety $\mathrm{x}$ version combinations. However, one must keep in mind for this 
multivariate analysis that results are dependent on the choice of distance among individuals and agglomeration method. For the latter, simulation studies have shown that there is not one best choice for all cases, even though Ward's minimum variance criterion was among those with the best overall performance [17], this is why we have chosen this criterion.

To compare the level of intra-varietal diversity between populations ( $\mathrm{N}$ versions) and the commercial variety, we calculated the Simpson's diversity index for qualitative criteria $\left(\Sigma_{\mathrm{i}} \mathrm{p}_{\mathrm{i}}\right.$, where $\mathrm{p}_{\mathrm{i}}$ are the frequencies of the different modalities) and the difference between the $90 \%$ and the $10 \%$ quantiles for the quantitative criteria.

\section{Results and Discussion}

\subsection{Changes within the Varieties}

Table 5 presents the mean values of the traits observed for original and farmers' versions for each variety and the significance of the observed differences.

Table 5. Mean values and statistical significance of changes $(\mathrm{p}<0.05)$, after two years of on-farm cultivation and selection, in the common experiment at Le Rheu in 2009: $\mathrm{m}_{\mathrm{N}}$ and $m_{N+2}$ where $m_{N}$ is the mean of the original seed lot and $m_{N+2}$ is the mean of the farmers' version after two growing cycles.

\begin{tabular}{lcccccccc}
\hline Variety & MLS & ALW & SUP & VER & VIK & VMA & \multicolumn{2}{c}{ EDR } \\
\hline Farmer & AVO & & \multicolumn{2}{c}{ MC } & & & FD \\
Petiole length & $\mathrm{m}_{\mathrm{N}}=83.6$ & 75.9 & 80 & 85 & 68 & 89 & 110 & 110 \\
(mm) & $\mathrm{m}_{\mathrm{N}+2}=74.6^{*}$ & $89.2 * * *$ & 71 & 92 & 70 & 95 & 102 & 99 \\
Leaf length & 164 & 143 & 150 & 166 & 146 & 152 & 150 & 150 \\
(mm) & 154 & $156^{*}$ & 141 & 169 & 143 & $174 * *$ & 160 & 147 \\
Leaf width & 135 & 119 & 138 & 127 & 139 & 113 & 112 & 112 \\
(mm) & 127 & 118 & $124 *$ & 136 & 140 & 123 & 118 & 109 \\
Color "L" & 42.8 & 40.9 & 39.5 & 43.3 & 41.3 & 41.7 & 42.5 & 42.5 \\
& 42.3 & 41.5 & 40.4 & 43.1 & $42.9 * *$ & 41.8 & 43.4 & 42.8 \\
Color “A" & -14.3 & -12.9 & -12.4 & -14.8 & -13.4 & -14.4 & -13.3 & -13.3 \\
& -14.1 & $-13.4 * * *$ & -12.9 & $-15.4 * *$ & $-14.3 *$ & -14.4 & -13.7 & -12.6 \\
Color "B" & 20.7 & 18.2 & 16.7 & 22.1 & 18.0 & 20.3 & 18.6 & 18.6 \\
& 19.9 & $19.2 * * *$ & 17.1 & $23.0 *$ & $19.4 *$ & 20.6 & $19.9 * *$ & 18.3 \\
Anthocyanin & 1.00 & 1.00 & 1.00 & 1.44 & 1.00 & 1.04 & 1.21 & 1.21 \\
(note 1 or 0) & 1.00 & 1.00 & 1.00 & 1.49 & 1.00 & 1.07 & $1.37 *$ & $1.45 *$ \\
Petiole attitude & 1.82 & 1.91 & 1.98 & 2.18 & 2.42 & 2.22 & 2.26 & 2.26 \\
(note from 1 to 3) & 1.84 & $2.27 *$ & 1.64 & 2.16 & $2.06 * *$ & 2.32 & 2.30 & 2.21 \\
Leaf attitude & 2.00 & 2.02 & 1.84 & 1.73 & 2.74 & 1.87 & 1.84 & 1.84 \\
(note from 1 to 4) & 1.93 & 2.09 & $2.07 *$ & 1.67 & 2.81 & 1.52 & 1.67 & 1.59 \\
\hline
\end{tabular}


Table 5. Cont.

\begin{tabular}{|c|c|c|c|c|c|c|c|c|}
\hline Variety & MLS & ALW & SUP & VER & VIK & VMA & \multicolumn{2}{|c|}{ EDR } \\
\hline Farmer & AVO & \multicolumn{5}{|c|}{$\mathrm{MC}$} & & FD \\
\hline Shape of apex & 2.39 & 2.95 & 2.63 & 2.05 & 2.93 & 2.48 & 2.37 & 2.37 \\
\hline (note from 1 to 3 ) & 2.21 & 2.79 & 2.58 & 1.93 & 2.94 & 2.07 & $1.90^{*}$ & $1.79 * *$ \\
\hline Thickness & 4.20 & 3.96 & 3.43 & 4.36 & 3.68 & 3.44 & 3.74 & 3.74 \\
\hline (note from 1 to 5 ) & 4.02 & 3.89 & 3.48 & 4.09 & 3.44 & 3.95 & $4.30^{*}$ & 3.79 \\
\hline Blistering & 2.82 & 3.04 & 3.18 & 2.71 & 3.03 & 2.27 & 1.74 & 1.74 \\
\hline (note from 1 to 5 ) & 269 & 2.96 & 3.11 & 2.78 & $3.41^{*}$ & 2.48 & 1.63 & 1.66 \\
\hline Intensity of green & 2.87 & 3.96 & 4.37 & 2.38 & 3.26 & 2.36 & 3.21 & 3.21 \\
\hline (note from 1 to 5 ) & 3.02 & 3.51 & 4.11 & 2.38 & 3.09 & 2.48 & 3.13 & 3.10 \\
\hline Bolting index, & 1.00 & 0.67 & 0.67 & 1.67 & 0.33 & 2.67 & 2.00 & 2.00 \\
\hline $\begin{array}{l}\text { May 22, } 2009 \\
\text { (note from } 0 \text { to 3) }\end{array}$ & 0.67 & $2.33^{* * *}$ & 1.00 & 1.67 & 0.67 & $3.00^{*}$ & $2.50^{*}$ & $2.50 *$ \\
\hline Bolting index, & 1.33 & 2.00 & 1.67 & 3.00 & 2.67 & 3.00 & 3.00 & 3.00 \\
\hline $\begin{array}{l}\text { May 29, } 2009 \\
\text { (note from } 0 \text { to 3) }\end{array}$ & $1.00 *$ & $3.00^{* * *}$ & 2.00 & 3.00 & 2.33 & 3.00 & 3.00 & $2.50 *$ \\
\hline Bolting index, & 2.67 & 3.00 & 2.67 & 3.00 & 3.00 & 3.00 & 3.00 & 3.00 \\
\hline $\begin{array}{l}\text { June } 4,2009 \\
\text { (note from } 0 \text { to } 3 \text { ) }\end{array}$ & 2.67 & 3.00 & $3.00^{*}$ & 3.00 & 3.00 & 3.00 & 3.00 & 3.00 \\
\hline Flowering index, & 0.00 & 0.00 & 0.33 & 0.00 & 0.00 & 2.00 & 1.00 & 1.00 \\
\hline $\begin{array}{l}\text { May 22, } 2009 \\
\text { (note from } 0 \text { to 3) }\end{array}$ & 0.00 & $1.33^{* * *}$ & 0.33 & 0.00 & 0.00 & 2.00 & $2.00^{* * *}$ & $1.50^{*}$ \\
\hline Flowering index, & 1.33 & 1.33 & 0.67 & 1.00 & 1.33 & 2.67 & 2.50 & 2.50 \\
\hline $\begin{array}{l}\text { May 29, } 2009 \\
\text { (note from } 0 \text { to 3) }\end{array}$ & $0.33 * * *$ & $2.00^{* * *}$ & $1.33 * * *$ & $2.00 * * *$ & 1.33 & 2.67 & 2.50 & $2.00^{*}$ \\
\hline Flowering index, & 2.00 & 2.00 & 2.33 & 2.33 & 2.00 & 3.00 & 3.00 & 3.00 \\
\hline $\begin{array}{l}\text { June } 4,2009 \\
\text { (note from } 0 \text { to } 3 \text { ) }\end{array}$ & 1.67 & $3.00^{* * *}$ & 2.33 & 2.67 & 2.00 & 3.00 & 3.00 & 3.00 \\
\hline
\end{tabular}

Varieties: 'Alwaro' (ALW), 'Monarch Long Standing' (MLS), 'Supergreen' (SUP), 'Verbeterde Hollandia' (VER), 'Viking' (VIK), 'Viking Matador' (VMA), 'Eté de Rueil’ (EDR).

P-value (p) of ANOVA or Chi-2 (for qualitative traits, in italic) for the difference $\mathrm{m}_{\mathrm{N}+2}-\mathrm{m}_{\mathrm{N}}$ : non statistically significant $(\mathrm{p}>0.05)$, $* \mathrm{p}<0.05, * * \mathrm{p}<0.01, * * * \mathrm{p}<0.001$.

Significant differences between the original version and the version cultivated by farmers were detected on at least one trait for all the varieties and for all traits, except for intensity of green color.

Most of the varieties showed significant changes for the A and B parameters of color, bolting and flowering indexes (three to five). Morphological traits (leaf attitude, thickness or blistering) were the traits that evolved the least. Intensity of green did not show significant changes for any of the varieties. We studied (data not shown) the correlation between the visual intensity of green score (from one to five) and each parameter of the chromameter (L, A and B) separately. Visual observation and 
chromameter parameters were always well correlated, for example, decreasing intensity of green (most of the cases observed in the table above) corresponded with increasing of L value ("whiter"), decreasing of A value ("greener") and increasing of B value ("more yellow"). Thus, we can conclude that there were changes of color in some cases even if the visual intensity of green score did not show significant changes. The chromameter measurements completed the visual observations because they decomposed the different dimensions of color, which the eye cannot do.

All varieties showed statistically significant, $\mathrm{p}<0.05$ changes within different measured traits for each variety. Some varieties changed for only one or a few traits ('Monarch Long Standing', 'Verbeterde Hollandia' and 'Viking Matador'), whereas others showed changes for a greater number of traits ('Alwaro', 'Viking' or 'Eté de Rueil'). Figure 4 illustrates the different amplitudes of changes with two varieties: 'Verbeterde Hollandia' and 'Alwaro'.

Figure 4. The photos show the two versions of variety 'Verbeterde Hollandia', which showed very few phenotypic changes and the two versions of variety 'Alwaro' which showed several significant phenotypic changes over the two years of on-farm cultivation.

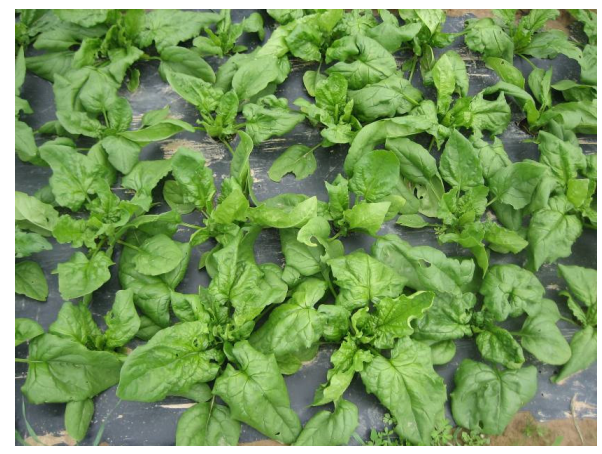

'Verbeterde Hollandia'-year N + 2, farmer MC version

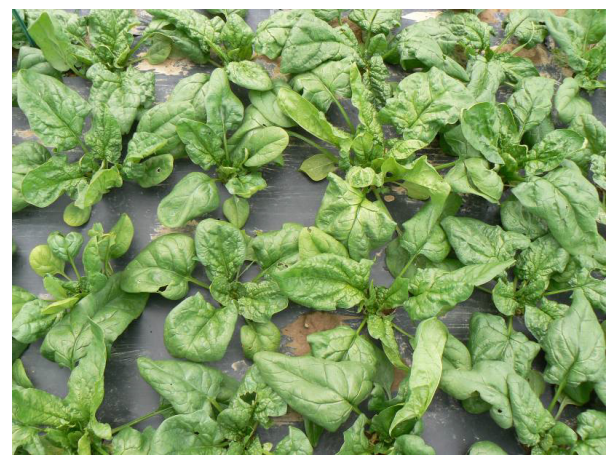

'Alwaro'-year N + 2, farmer MC version

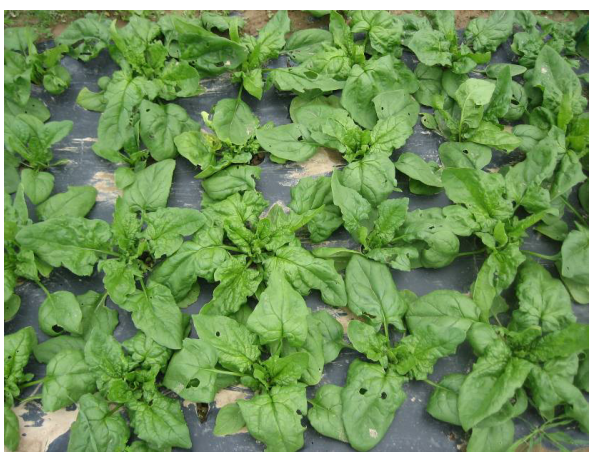

'Verbeterde Hollandia'-year N original version

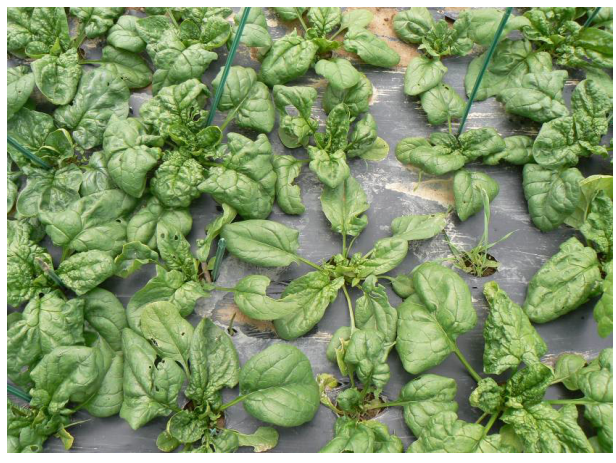

'Alwaro'-year N original version

'Alwaro' is the variety that showed the most differences between the original and farmer's (MC) versions. $\mathrm{MC}$ version has significantly longer petioles and leaves $(+1.3 \mathrm{~cm}$ for both relatively to original version). Color showed significant changes for parameter A (decrease, "greener") and parameter B (increase, "more yellow"). MC version had more erected petioles and is earlier to bolt and flower than the original (five development indexes are different from the original version). 
'Eté de Rueil' was cultivated by two different farmers (MC and FD). Changes were observed on both farms but were not identical. Indeed, the $\mathrm{MC}$ version changed significantly for the $\mathrm{B}$ color parameter and leaf thickness (the MC version was thicker than original version). Both the MC and FD versions had more plants with anthocyanin, more rounded leaves and both were earlier to bolt and flower than the original version. It is interesting to note that when both MC and FD versions showed differences, it was always in the same direction.

'Monarch Long Standing' changed for the petiole length and two bolting indexes (the AVO version was later than the original version). The MC version of 'Supergreen' had narrower and more erect leaves than the original version. It was also earlier for two development indexes. 'Verbeterde Hollandia' showed modifications for two color parameters (A and B) and for one flowering index (the $\mathrm{MC}$ version was earlier than the original version). $\mathrm{MC}$ version of 'Viking' showed changes for all the color parameters (L, A and B) and had also less erect petioles and more blistered leaves than the 'Viking' original version. 'Viking' differs from the others varieties by the fact that it did not change for any phenological trait while all other varieties showed changes for at least one of those traits. 'Viking Matador' showed changes for two traits: MC version had longer leaves and was earlier than original version for one bolting index.

Based on the ascending hierarchical classification (AHC), we classified all the versions of all the varieties considering all the traits observed (except bolting and flowering indexes) (Figure 5). We can draw two observations from Figure 5. If we separate the tree into six groups, each group comprises the different versions of a single variety except two groups that contain one version of 'Alwaro' each (and thus there is no 'Alwaro' group). If we separate the tree into two groups, the two versions of 'Alwaro' are still in different groups, in contrast to the different versions of all the other varieties, which are always in the same group. The varieties appear to have changed but conserved their phenotypic identity, except 'Alwaro,' which seems to have significantly diverged from its original version. AHC confirms the field observations and the results of individual trait analysis: 'Alwaro' is the variety that shows the most phenotypic changes. According to the AHC, the 'Alwaro' original version is close to 'Supergreen' and 'Alwaro' MC is close to 'Viking Matador'.

From these two first analyses (Table 5 and Figure 5), we observed that all the varieties tested showed changes for at least one trait, but they conserved their variety identity (the different versions of each variety were always grouped in the AHC). 'Alwaro' is a particular case as it has changed significantly for morphological and development aspects and it may be appropriate to consider it two different varieties at this point in time. For such a short period of time (two years), we were not expecting many phenotypic changes, and expected phenological criteria to change more often than morphological traits. However, the traits used as varietal descriptors often showed significant changes and this surprised us. We next discuss different explanatory factors that could contribute to the observed changes. 
Figure 5. Ascending Hierarchical Classification (AHC) of the different varieties for all the measured morphological traits. The dotted line is drawn to split the tree into six groups.

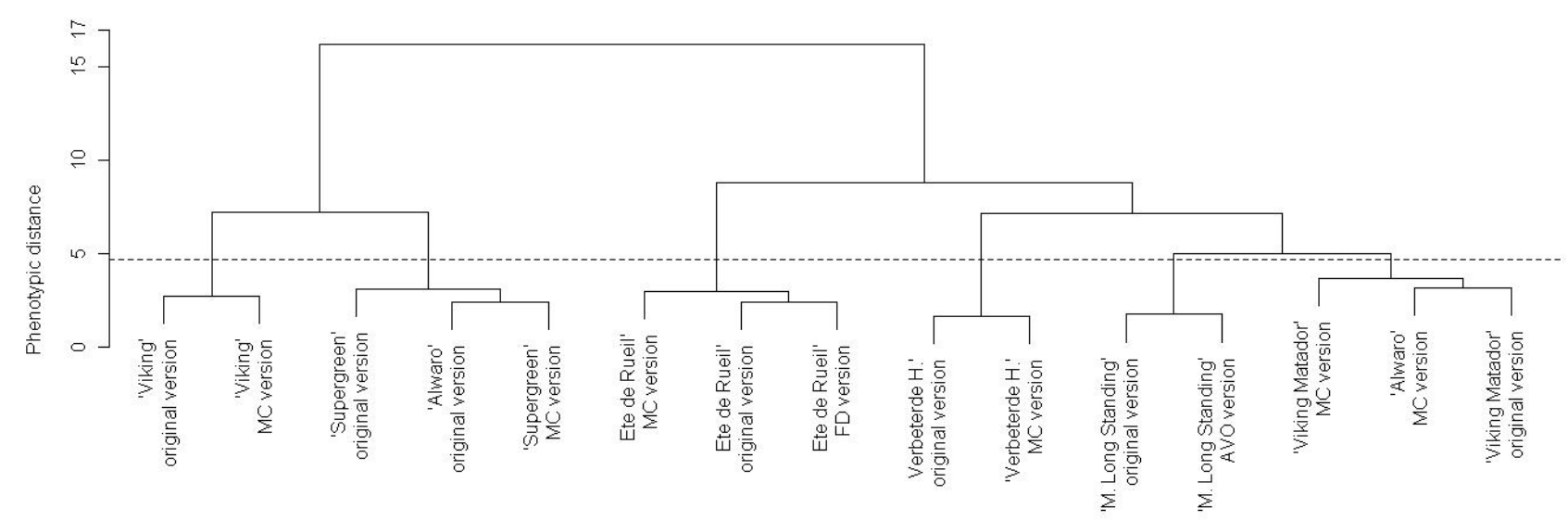

The choice of the experimental method was based on the method of DUS testing, but we also wanted to detect fine changes, for which the DUS method is not adapted. This is why we chose to observe one representative leaf per plant on a representative sample of individual plants instead of taking one measurement on the population in its entirety (the DUS method). Spinach plants are difficult to characterize because the harvested organ is the leaf, during the vegetative growth period of the plant. Furthermore, as each plant has multiple leaves, one observation does not necessarily represent the plant in its entirety, as could be considered for the maize ear for example. However, we tried to balance this potential source of error by sampling a large number of individuals per plot and rigorously adhering to a set protocol in leaf selection and measurement.

Other than the phenological traits, all the traits we observed are also included in DUS tests. These are traits that display genetic differences between varieties and that are not too much influenced by the environment. This is also likely the case for phenologicaly traits, which are of adaptive significance, as is known in other species [14]. Most of these traits are also likely quantitatively inherited. Therefore, we expected they would react to natural and/or human selection. The changes observed can thus be linked with natural adaptation (pressure of the environment), possibly farmers' selection, and also a certain degree of chance (genetic drift or accidental pollination during the multiplication phase, even though multiplication was controlled very carefully). The changes could also be due to different multiplication methods. Varieties coming from gene banks are maintained with a strict scheme, with the aim of conserving a specific phenotype of the variety. The method applied by farmers differed from this scheme and this could explain part of the observed changes.

At the least, we can say that the varieties tested in this study have changed in only two years of cultivation. We interviewed farmers on their selection criteria throughout the project to see if human selection could have had a directional influence on the phenotypic changes observed. 


\subsection{Effect of Farmer Selection on Changes in the Varieties}

Selection criteria applied by the three farmers of this study are described in Table 3.

AVO selected plants only on precocity and 'Monarch Long Standing' has evolved on this aspect in the direction wished by the farmer (earlier bolting and flowering on 29 May).

'Eté de Rueil' showed changes for six criteria after cultivation at FD although no human selection was applied. It is interesting to note that the variety evolved in the same way when selected by MC.

$\mathrm{MC}$ selected all the varieties chosen according to the same criteria. All the varieties showed changes but not always in the direction he wished. For example, although MC selected dark plants later to bolt and flower, we noted that, on the whole, most of $\mathrm{MC}$ versions had a shorter cycle and whiter, "more yellow" and "greener" leaves (changes that we can interpret as "lighter green" according to the correlations observed between intensity of green and the L, A and B color parameters, data not shown). MC also selected plants with spear shaped leaves. Three varieties showed narrower or longer leaves ('Supergreen', 'Viking Matador' and 'Alwaro'), which tended towards a spear shape. From those results, it does not seem possible to distinguish which changes were due to the environment, human selection or others factors: human selection did not always produce changes in the direction wished by the farmer, and FD did not perform any selection and this variety did show phenotypic changes.

We measured changes as a difference between the phenotypic expressions of two versions of the same variety. However, even if we recorded the selection criteria of the farmers, we cannot say that we only measured the adaptive response to farmers' selection. The phenotypic expression of the plants depends on the genotype of the plant, and also on the environment (especially for spinach, which is very sensitive to nitrogen and water for example). Our study in the last year of the project took place in a different environment than the on-farm environments of selection/adaptation of the varieties. So, for example, although our observations underline that $\mathrm{MC}$ versions are earlier than the original versions, we cannot claim that MC failed in his selection of plants late to bolt and flower. MC's versions are earlier in our trial conditions, but perhaps not in its farm conditions. We know that he cultivated the spinach under plastic tunnels, and the second year the trial was conducted in winter instead of spring. Thus, when the seeds produced in these conditions were cultivated in our trial conditions (in spring in the field), we cannot conclude that the changes observed would have been the same at MC's farm.

In order to evaluate the efficiency of farmers' selection (or adaptive response to selection pressure), farmers planted their versions of the spinach varieties alongside the original versions in the last year of the project. The results of these on-farm trials were not statistically exploitable because farmers did not sow replicates, but this allowed the farmers to visually compare the varieties that they had selected to the original versions. We can report some observations made by the farmers without quantitative evaluations. For example, at MC, selected versions of the varieties were globally less blistered (a desired change) and at AVO, the original version of 'Monarch Long Standing' was earlier to bolt even though AVO had selected only the plants late to bolt. Unfortunately, the last year of the trial failed at FD due to weather conditions. The on-station and on-farm trials were complementary, as the on-station trial could evaluate the changes of varieties at a global level (all varieties coming from different farms) while the on-farm trials allowed farmers to evaluate the efficiency of their selection.

In this study, MC and AVO applied selection pressure and FD let the variety respond to natural selection. However, the types of changes observed were similar whether in response to natural or 
farmers' selection. So in our case, the type of selection (natural or human) does not seem to have an influence on the intensity of changes (the degree of significance and number of traits with significant differences). Changes in the FD version of 'Eté de Rueil' are comparable to changes in the MC version and even to the changes in other varieties. This shows the importance of so-called "natural evolution" or importance of the environmental impacts for cultivated plants. We can wonder if this capacity to respond to selection pressure could be linked with the allogamous reproductive strategy of spinach. However, in an article by Dawson [10] on a similar experimentation of the Farm Seed Opportunities project on wheat, an autogamous species, the same kind of results are shown for population varieties subjected to natural selection on-farm. It would be of interest and importance for breeding to compare the intensity and efficiency of human and natural selection in terms of the adaptive potential of the varieties. With this view, a more thorough experimentation would be needed where all varieties are selected by farmers in each environment, alongside the variety cultivated with only natural selection pressure.

\subsection{Homogeneity of the Varieties}

For quantitative criteria, levels of heterogeneity varied according to the variety, but the F1 hybrid was not specifically less heterogeneous than the other varieties. Except for the FD version of 'Eté de Rueil', which always had a higher level of heterogeneity, differences of heterogeneity levels between other farmers' versions and their respective original version were observed, but without a systematic pattern. For qualitative criteria, levels of homogeneity of the farmers' version were almost always comparable to those of the respective original versions or to the F1 hybrid. No significant differences were observed. Figure 6 gives an example of the results observed for qualitative criteria.

There was no correlation between changes in mean values observed in the varieties and their heterogeneity, or between changes in mean values and changes in the level of heterogeneity within versions of a variety. Simpson's diversity index (calculated for qualitative traits) and the interquantile range (calculated for quantitative traits) do not distinguish the F1 hybrid from the other varieties tested. Furthermore, the farmers' versions of varieties appeared to have conserved their level of heterogeneity whether they were selected or not.

When there was divergence in the mean values of different versions of the same variety, the intra-varietal diversity may have increased even if within each version, the same amount of phenotypic diversity exists compared with the original version. Each version may have the same internal level of diversity, but the global diversity represented by all the versions of the variety may have increased. This has been demonstrated by Goldringer et al. for phenotypic changes and diversity of agromorphological traits in wheat populations subjected to selection pressure in contrasting environments [18]. This new diversity and the rapidity of the changes observed indicate that population varieties may be good starting points for on-farm selection and adaptation. 
Figure 6. An example of intra-varietal heterogeneity of the different spinach varieties for the qualitative trait leaf blistering. Orange: F1 hybrid control; Red: original versions of population varieties; Green: MC versions; Maroon: FD version; Blue: AVO version.

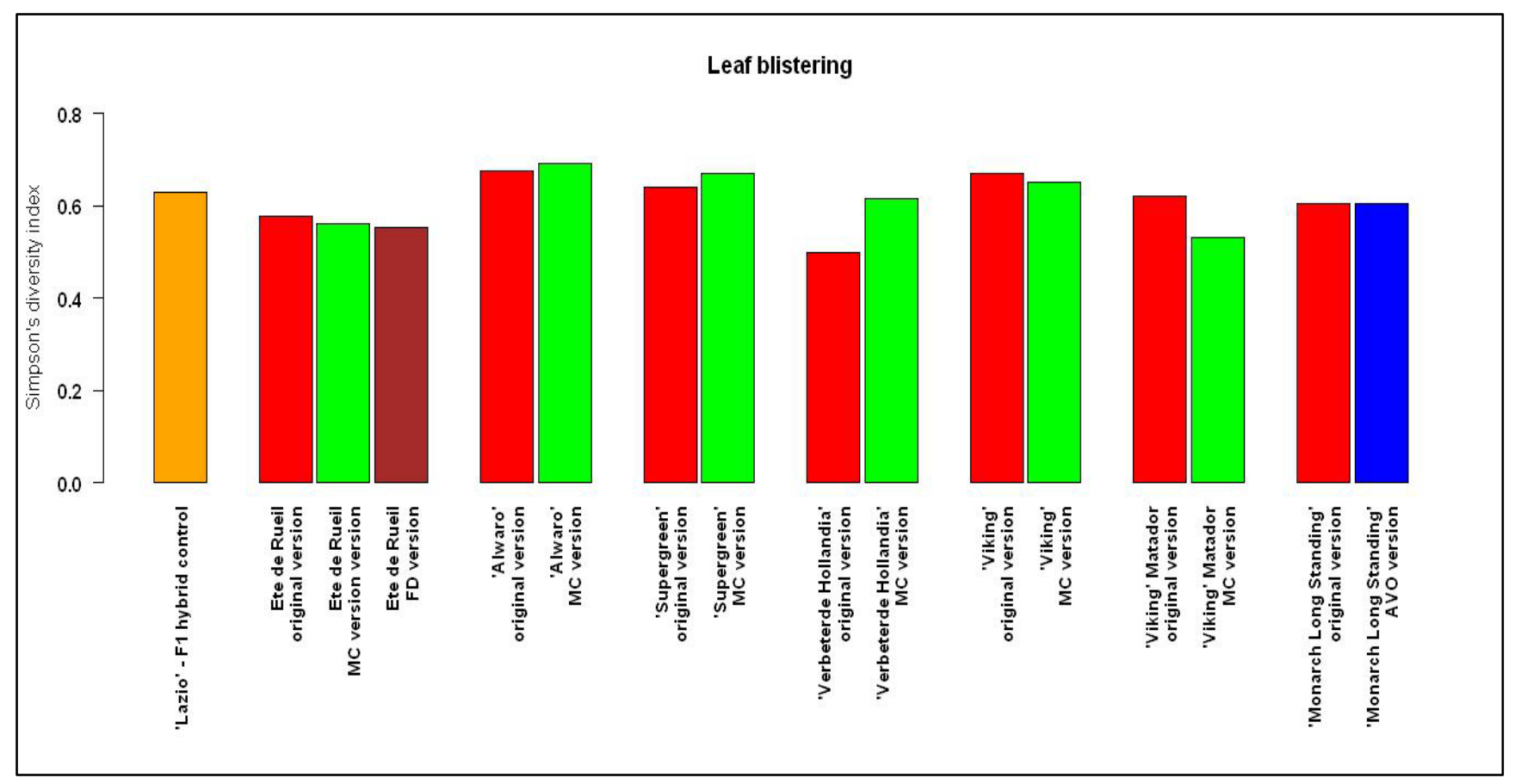

Farmer varieties are often said to be too diverse to meet the uniformity criterion of registration in the European Union, however, our study showed that the level of heterogeneity of the populations was often no different from that of the hybrid for traits used in the DUS evaluation. As the populations chosen for the experimentation were historically in the official catalog, they had to meet the uniformity criteria when they were initially registered. Even after they were removed from the catalog, they were conserved ex situ with very few plants and conservative selection during the regeneration process. However, our results question the assumption that $\mathrm{F} 1$ hybrids are always more uniform than population varieties; this appears not to be the case for many traits under organic conditions.

\section{General Discussion and Perspectives}

We found phenotypic changes in population varieties of spinach after two generations of on-farm breeding. But have the varieties changed so much that they are no longer distinct? The results of the ascending hierarchical classification clearly showed that one variety has evolved to such a point that its two versions were not in the same group. This leads to certain questions about what constitutes a new variety in this context, where limit is between one variety and another, and how can we define and measure variety distinctness for population varieties. From a scientific point of view, we would like to understand the reasons for the phenotypic changes (and maybe evolution) of a variety, and how the adaptive and evolutionary potential of varieties can be conserved. The changes observed within tested populations after two generations would cause this type of variety to be rejected from catalogue registration based on the criterion of stability of the European catalogue varieties. Seed companies or gene banks that maintain open pollinated populations practice conservative selection based on a certain phenotypic description of the variety, which may eliminate genetic diversity that was initially present. 
In our case, farmers chose varieties corresponding to their own criteria, and then selected the variety based on their objectives. The two processes are different and complementary in terms of maintaining useful genetic diversity in agricultural species, and our results are specific to on-farm conservation and breeding where farmers are seeking varieties with more variability, as discussed in the introduction.

The possibilities for adaptation of the varieties to specific environmental conditions are enhanced by their intrinsic variability. This is promising for farmers who would like to adapt populations to their own conditions (environments and markets) and it is of great interest for organic and low input agriculture in which chemical inputs are prohibited. Farmers' use of their own saved seed is also related to the sustainability of farms from an economic perspective. If farmers can make the varieties evolve according to their own objectives and markets, they would not need to buy seeds for each crop and each year and their autonomy would be enhanced. It is one of the conclusions of the FSO Project that the regulation should be re-valuated in order to create a specific framework for population varieties and seed saving activities where varieties are not stable as defined by the current catalogue regulation [1]. However, registration is not necessarily an issue in on-farm breeding activity. Farmers involved in PPB have organized seed associations to manage breeding and seed exchanges [19], and those activities constitute a separate seed system from the dominant commercial seed system.

\section{Conclusions}

This study showed that the populations tested have phenotypically changed over two years of on-farm cultivation and selection. The changes detected in such a short period of time are a sign that the observed population varieties could be adapted to diverse conditions. It is of great interest for organic and low input farmers who are interested in developing their own varieties and adapting them to their particular conditions. There is a need for further research on the evolution of farmer varieties, specifically related to biological questions of adaptability and evolutionary capacities of allogamous crops and how the legislative framework take into account the biological reality of those varieties, recognizing the farmers' role in creating and maintaining genetic diversity in cultivated species.

\section{Acknowledgments}

We wish to thank the farmers involved in this study. We also thank the European Community for funding the Farm Seed Opportunity project (FP6 STREP, contract no. 044345, priority 8.1, "Specific Support to Policies").

\section{Conflict of Interest}

The authors declare no conflict of interest.

\section{References and Notes}

1. Chable, V.; Louwaars, N.; Hubbard, K.; Baker, B.; Bocci, R. Plant breeding, variety release and seed commercialisation: Laws and policies of concern to the organic sector. In Organic Crop Breeding; Lammerts van Bueren, E.T., Myers, J.R., Eds.; Wiley-Blackwell: Hoboken, NJ, USA, in press. 
2. Wood, D.; Lenne, J.M. The conservation of agrobiodiversity on-farm: Questioning the emerging paradigm. Biodivers. Conserv. 1997, 6, 109-129.

3. Lammerts van Bueren, E.T. Ecological concepts in organic farming and their consequences for an organic crop ideotype. Neth. J. Agric. Sci. 2002, 50, 1-26.

4. Colley, M.R.; Navazio, J.P. New F1 and open-pollinated spinach varieties for organic systems: A farmer, seed company, and non-profit model of participatory breeding. In Abstract Book of Eucarpia Symposium Plant Breeding for Organic and Sustainable, Low-Input Agriculture: Dealing with Genotype-Environment Interactions, 7-9 November 2007, Wageningen, The Netherlands; Lammerts van Bueren, E.T., Østergård, H., Goldringer, I., Scholten, O., Eds.; Wageningen University: Wageningen, The Netherlands; p. 69.

5. Ceccarelli, S.; Grando, S. Decentralized participatory plant breeding: An example of demand driven research. Euphytica 2007, 155, 349-360.

6. Chable, V.; Conseil, M.; Serpolay, E.; Le Lagadec, F. Organic varieties for cauliflowers and cabbages in Brittany: From genetic resources to participatory plant breeding. Euphytica 2008, 164, 521-529.

7. Murphy, K.; Lammer, D.; Lyon, S.; Carter, B.; Jones, S.S. Breeding for organic agriculture and low-input farming systems: An evolutionary-participative breeding method for inbred cereal grains. Renewable Agric. Food Syst. 2004, 20, 48-55.

8. Newton, A.C.; Akar, T.; Baresel, J.P.; Bebeli, P.J.; Bettencourt, E.; Bladenopoulos, K.V.; Czembor, J.H.; Fasoula, D.A.; Katsiotis, A.; Koutis, K.; Koutsika-Sotiriou, M.; et al. Cereal landraces for sustainable agriculture: A review. Agron. Sustain. Dev. 2010, 30, 237-269.

9. Philipps, S.L.; Wolfe, M.S. Evolutionary plant breeding for low-input systems. J. Agric. Sci. 2005, 143, 245-254.

10. Dawson, J.C.; Serpolay, E.; Giuliano, S.; Schermann, N.; Galic, N.; Osman, A.; Pino, S.; Goldringer, I. Phenotypic diversity and evolution of farmer varieties of bread wheat in organic agricultural systems in Europe. Sustainability, in press.

11. Kumar, S.; Bisht, I.S.; Bhat, K.V. Population structure of rice (Oryza sativa) landraces under farmer management. Ann. Appl. Biol. 2010, 156, 137-146.

12. Pressoir, G.; Berthaud, J. Population structure and strong divergent selection shape phenotypic diversification in maize landraces. Heredity 2004, 92, 95-101.

13. Vaz Patto, M.C.; Moreira, P.M.; Almeida, N.; Satovic, N.; Pego, S. Genetic diversity evolution through participatory maize breeding in Portugal. Euphytica 2008, 161, 283-291.

14. Goldringer, I.; Prouin, C.; Rousset, M.; Galic, N.; Bonnin, I. Rapid differentiation of experimental populations of wheat for heading time in response to local climatic conditions. Ann. Bot. 2006, 98, 805-817.

15. Chable, V.; Goldringer, I.; Dawson, J.; Bocci, R.; Lammerts van Bueren, E.T.; Serpolay, E.; Gonzalez, J.M.; Valero, T.; Levillain, T.; Van der Burg, J.W.; et al. Farm seed opportunities: A project to promote landrace use and renew biodiversity. In Bioversity Technical Bulletin, No. 15; Negri, V., Maxted, N., Vetelainen, M., Eds.; Bioversity International: Rome, Italy, 2009, pp. 266-274. 
16. R Development Core Team. R: A language and environment for statistical computing. $\mathrm{R}$ Foundation for Statistical Computing: Vienna, Austria; Available online: http://www.Rproject.org/; 2011 (accessed on 2 September 2011).

17. Milligan, G.W. A review of Monte Carlo Tests of cluster analysis. Multivariate Behav. Res. 2008, 16, 379-407.

18. Goldringer, I.; Paillard, S.; Enjalbert, J.; David, J.L.; Brabant, P. Divergent evolution of wheat populations conducted under recurrent selection and dynamic management. Agronomie 1998, 18, 413-425.

19. Chable, V.; Le Lagadec, F.; Supiot, N.; Léa, R. Participatory research for plant breeding in Brittany, the Western region of France: Its actors and organisation. In Proceedings of the 1st IFOAM Conference on C7-Organic Animal and Plant Breeding, Breeding Diversity, Santa Fe, NM, USA, 25-28 August 2009.

(C) 2011 by the authors; licensee MDPI, Basel, Switzerland. This article is an open access article distributed under the terms and conditions of the Creative Commons Attribution license (http://creativecommons.org/licenses/by/3.0/). 